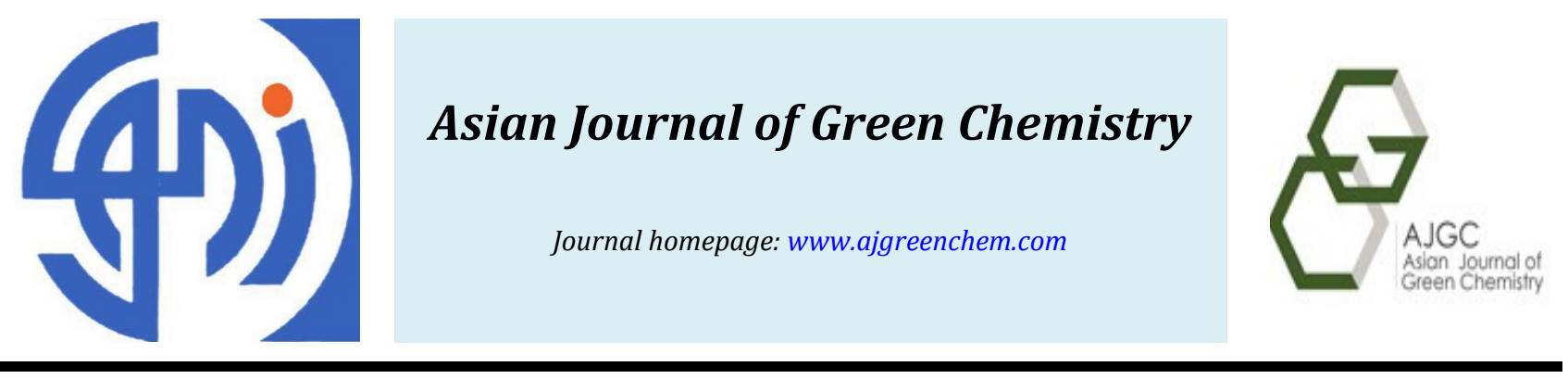

Original Research Article

\title{
Application of modified sawdust for solid phase extraction, preconcentration and determination of trace lead in water samples
}

\author{
Rashin Andayesha,*, Shahla Elhami ${ }^{\mathrm{b}}$ \\ a Department of Chemistry, Khouzestan Science and Research Branch, Islamic Azad University, Ahvaz, Iran \\ b Department of Chemistry, Ahvaz Branch, Islamic Azad University, Ahvaz, Iran
}

\section{ARTICLE INFORMATION}

Received: 17 November 2018

Received in revised: 4 February 2019

Accepted: 4 February 2019

Available online: 2 March 2019

DOI: 10.33945/SAMI/AJGC/2019.4.10

\section{KEYWORDS}

Preconcentration

$\mathrm{Pb}$ (II)

Sawdust

Diethylenetriamin

Solid phase extraction

\begin{abstract}
A new sorbent was prepared for separation and preconcentration of $\mathrm{Pb}$ (II) by using the flame atomic absorption spectrometry. The normative studies on extraction, separation and preconcetration of $\mathrm{Pb}$ (II) were represented in this work. This novel method was based on new sorbent by adding diethylenetriamine to sawdust, increasing the incidence exterior. The effect of different parameters including, $\mathrm{pH}$, ligand concentration and sample volume, type and volume of eluent and ligand effect were studied. The optimum $\mathrm{pH}$ and preconcentration factor and limit of detection for $\mathrm{Pb}$ (II) were 4,100 , and $0.48 \mu \mathrm{g} / \mathrm{L}$, respectively. In addition, the calibration curve was linear in the range of $0.05-100 \mathrm{mg} \cdot \mathrm{mL}^{-1}$ with $\mathrm{R}^{2}=0.995$. The vertical and horizontal confines of calibration diagrams in $500 \mathrm{~mL}$ solution were calculated about $0-0.5 \mathrm{mg} \mathrm{L}^{-1}$ and $0-0.6$. The results of applying the present method to determinate the separated lead ions in water samples were prosperous and harmonious. Precision of the method was investigated by comparing them with the observations from previous similar researches.

(C) 2019 by SPC (Sami Publishing Company), Asian Journal of Green Chemistry, Reproduction is permitted for noncommercial purposes.
\end{abstract}




\section{Graphical Abstract}

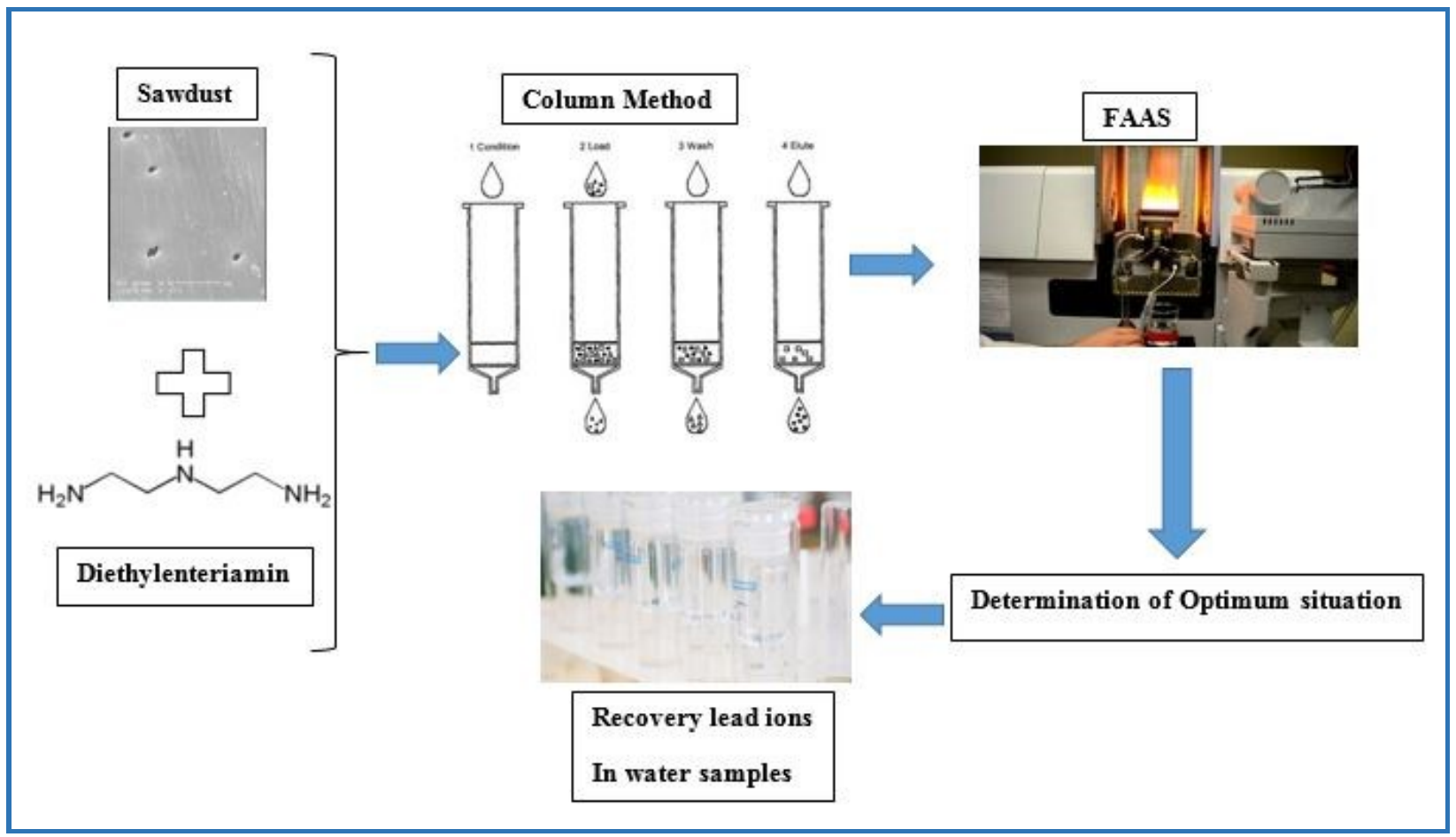

\section{Introduction}

Various kinds of toxic heavy metals containing cadmium, lead, cobalt, copper, arsenic, zinc and Hg enter the environment through mineral production, industrial discharges, pollutions, and dissolution of agriculture lands [1-3]. Lead has a wide range of application among thw heavy metals. Tetraethyl and tetramethyl lead which penetrate in fluids and food chain are the main source of environment's pollutions [4]. Lead has many detriments for human health and may accumulate at liver, bones, and muscles [5, 6]. Accordingly, precise determination of heavy metals in natural is the important part of analytical chemistry's studies [7, 8].

Flame atomic absorption spectrometry is a method with simple application and low triggering disbursement [9]. Manifestation limitation of this procedure causes the fact that preconcentration has been known as a necessary step before determination of heavy metals $[10,11]$. Membrane separation [12], liquid-liquid extraction [13], and solid phase extraction [14-16] were used for preconcentration and separation of metal ions prior measuring the heavy metals [17]. Simple setup and availability are the advantages of solid phase extraction in comparison with the other current methods. It is a known efficient procedure for separating the metal ions which may reduce the time and cost of conducting the experiments with high enrichment factor $[18,19]$. Many researchers have used different adsorbents such as resin [20], silica gel [21], and polyvinyl chloride [22] to 
preconentrate metal ions in various samples. High cost of keeping sorbents and providing them have the main role in getting proper efficiency and yield for the solid phase extraction methods [25]. Many studies have been conducted to find a low cost and effective sorbent for preconcentration of trace metals $[26,27]$.

One novel technology which includes absorption of solvated particles from natural samples, is called adsorption. Low cost, short-time design and further usage capability are some of the features of the adsorption method [28]. Among the surface adsorbent, sawdust is a high usage over plus and production of wooden industry which can be used as a low cost sorbent [29]. Some other sorbents were used to remove lead from hexamine, poli acrylamide and colored inks. In lead adsorption [30], there are just a few studies conducted on analytical usage of sawdust as low cost and safe adsorbent for separating lead ions from water samples.

In the present research study, the possibility of utilization of sawdust was examined as a simple and low price method for solid phase extraction of trace lead. So, lead ions were preconcentrated before the flame atomic absorption to determine the adsorbed lead particles from water samples existing in environment. Effects of different parameters such as $\mathrm{pH}$ of solution, kind and volume of solution and eluent and ligand influences were investigated. Performance and efficiency of the aforementioned method was studied for Dez river, Karkhe river and tap water samples.

\section{Experimental}

\section{Reagent and solutions}

All the materials which contain $\mathrm{Pb}\left(\mathrm{NO}_{3}\right)_{2}, \mathrm{C}_{4} \mathrm{H}_{13} \mathrm{~N}_{3}, \mathrm{HNO}_{3}$, $\mathrm{KI}$ and $\mathrm{HCl}$ were purchased from Merck company, Germany. In the present study, water which was used for providing solutions was distilled twice. $1.396 \mathrm{~g} \mathrm{~Pb}\left(\mathrm{NO}_{3}\right)_{2} .4 \mathrm{H}_{2} \mathrm{O}$ and distilled water were chosen for daily preparing of storage solution and a little more diluted solution. Standard solution was provided with suitable density before starting the experiment. All the glass and plastic instruments were eluted within diluted $\mathrm{HCl}$ and $\mathrm{HNO}_{3}$ and cleaned with distilled water. To prepare $1.2 \mathrm{~mol} / \mathrm{L}^{-1}$ acid nitric, $8.3 \mathrm{~mL}$ of high pure $\mathrm{HNO}_{3}$ was brought to volume with distilled water in a $100 \mathrm{~mL}$ flask.

\section{Apparatus}

To measure the absorption, a flame atomic absorption spectrometric from (model ICE 3000, America) was utilized. pH meter from ATC model (Serial no: GP353 Japan) was equipped to measure the pH of solution in queues phase, and GS300 model balance (Serial no: BS-3003 Japan) with $200 \mathrm{~g}$ capacity and accuracy of $0.001 \mathrm{~g}$ was used to assay the weight. 
Preparing sorbent

At first, sawdust was washed about 24 hours and then, it was dried at $110{ }^{\circ} \mathrm{C}$ and sieved by a 35 mm mesh. After that, $10 \mathrm{~g}$ of sawdust was mixed with $140 \mathrm{~mL}$ of dense $\mathrm{HCl}$. After one hour, $60 \mathrm{~mL}$ of diethylenetriamine was added to prepare the combination. After two hours, the mixture was eluted by distilled water and was located in a bottle in order to be dried for $18 \mathrm{~h}$ at $40{ }^{\circ} \mathrm{C}$.

\section{General procedure}

A mixture of $25 \mathrm{~mL}$ of $1 \mathrm{~mol} . \mathrm{L}^{-1} \mathrm{~Pb}$ solution and $4 \mathrm{~mL}$ of $1 \mathrm{~mol} . \mathrm{L}^{-1} \mathrm{KI}$ solution was spilled in a 500 $\mathrm{mL}$ glassware. The mixture was adjusted in $\mathrm{pH}=4$ by adding suitable amounts of $\mathrm{HNO}_{3}$ and distilled water. The prepared solution was passed through the column containing $0.25 \mathrm{~g}$ of the modified sorbent by diethylenetriamine. Then, the content of column was eluted by $5 \mathrm{~mL}$ of $1.2 \mathrm{~mol}^{-1} \mathrm{HNO}_{3}$. Finally, the accumulated solution of column was injected for the determination of the flame atomic absorption spectrometry.

\section{Results and Discussion}

\section{Characterization of sawdust}

Scanning electron microscopy (SEM) image of the sawdust, acidic sawdust, and the modified sawdust by diethylenetriamine was represented (Figure 1). SEM analysis was carried out to study the structure of sawdust before and after modification. As seen in Figure 1a, the sawdust's surface is relatively smooth. Figure $1 \mathbf{b}$ demonstrates a mixture of sawdust and $\mathrm{HCl}$, indicating that the configuration of surface was changed. Figure $1 \mathrm{c}$ illustrates the structure of the sawdust modified with diethylenetriamine which causes many groups to form and collect on the surface.

IR spectra analysis of three kinds of sorbent was measured at 400-4000 $\mathrm{cm}^{-1}$ limitation. The results for the pure sawdust, acidic sawdust and modified one are presented in Figure 2. The adsorption bands at 1439 to $1448 \mathrm{~cm}^{-1}$ are due to a contribution from $\mathrm{C}-\mathrm{H}$ stretching. The peaks at 1538 to $1637 \mathrm{~cm}^{-1}$ were assigned to the $\mathrm{C}=0$ bonds. The strong band was observed at $3422 \mathrm{~cm}^{-1}$ indicating the stretching of the $\mathrm{O}-\mathrm{H}$ band. The peak related to $\mathrm{O}-\mathrm{H}$ band for pure sawdust in Figure $2 \mathbf{a}$ is wider and sharper in the modified sawdust in Figure 2c. The peak of tensional $\mathrm{C}=0$ band was removed in Figure $2 \mathbf{b}$. Besides, the peak of $\mathrm{CN}$ band has a higher intensity in the modified state in Figure 2c. These observations showed that the instruction of the modified sawdust was changed. 


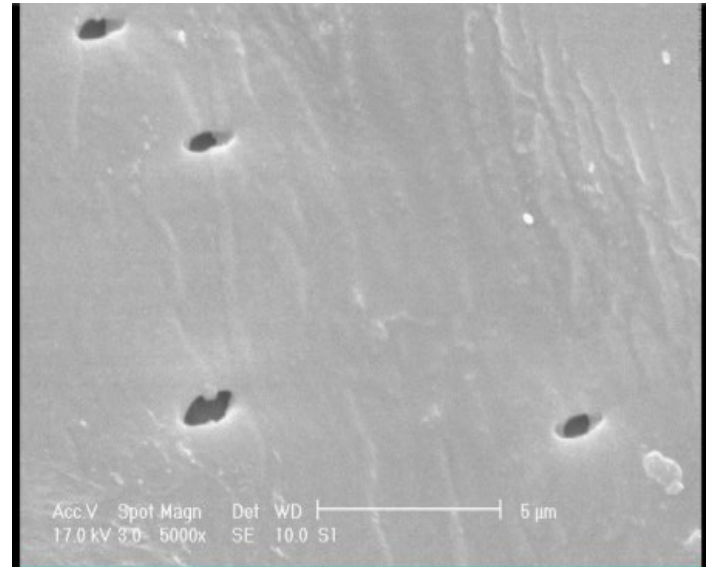

A

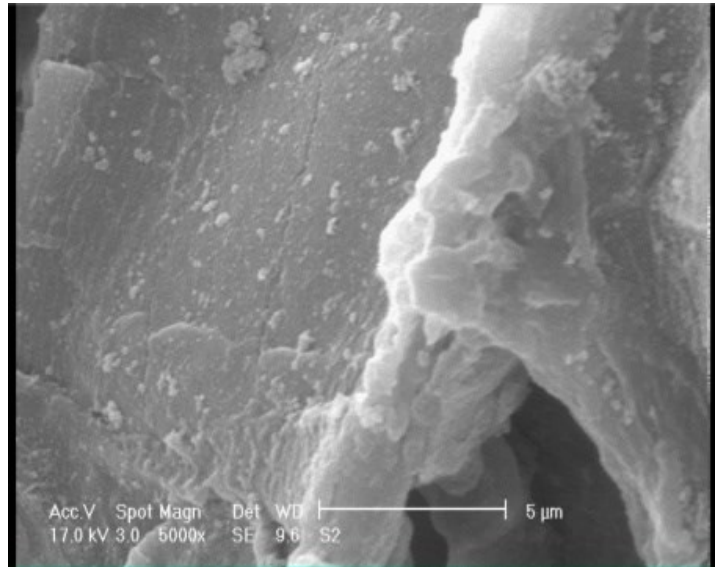

b

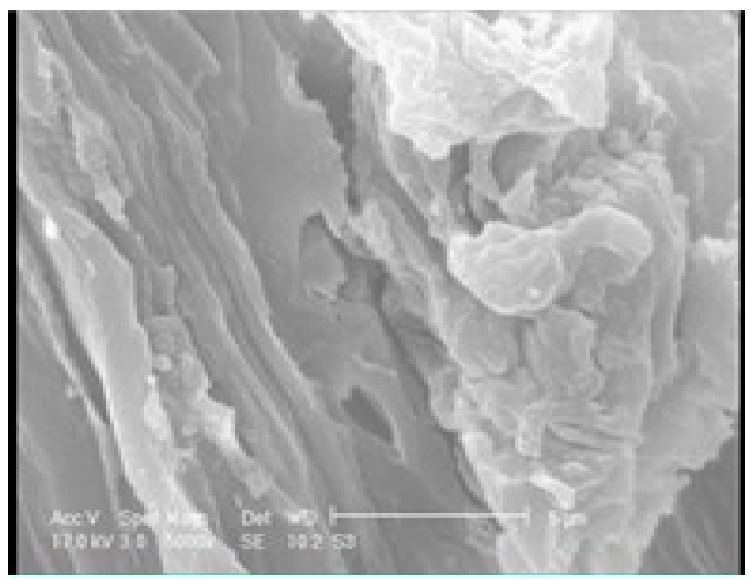

C

Figure 1. Scanning electron microscopy for a) sawdust, b) acidic sawdust, c) modified sawdust

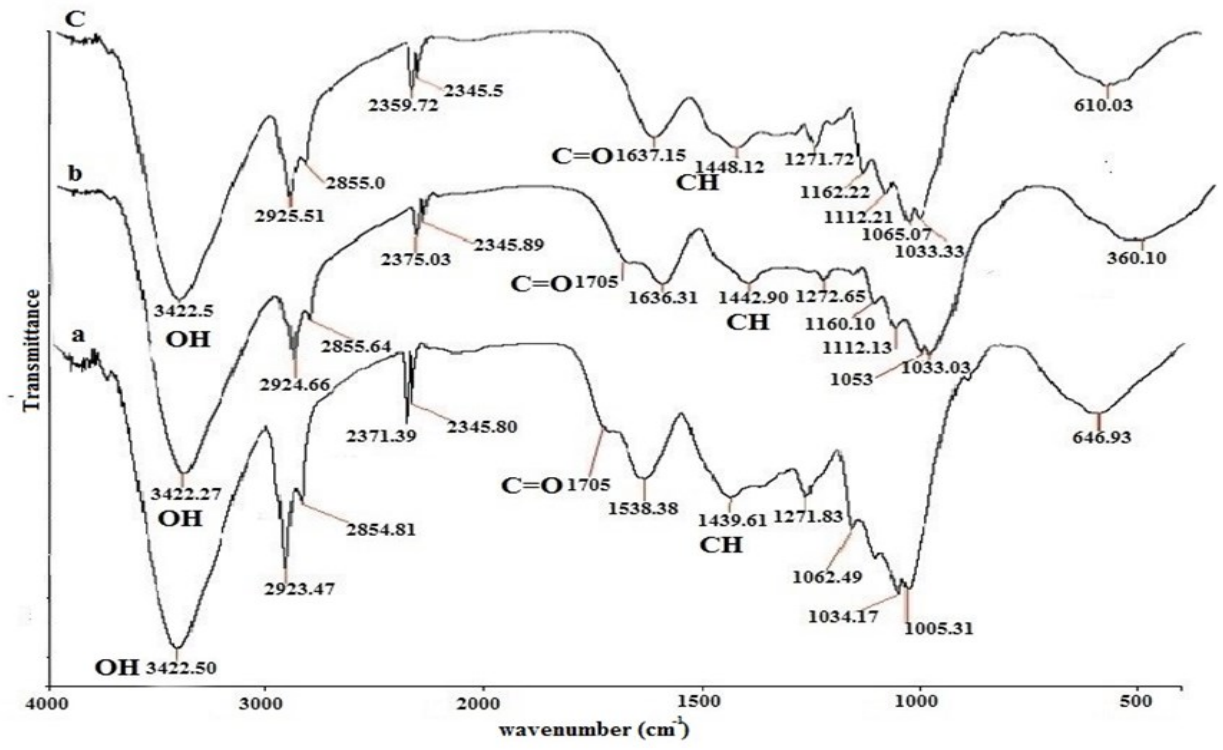

Figure 2. FT-IR spectra analysis for a) sawdust, b) acidic sawdust, c) modified sawdust [31, 32] Optimization of the effective parameters on lead's adsorption 
Empirical parameters including, $\mathrm{pH}$ of solution, the type of sorbent, ligand effect, type and volume of eluent were studied to obtain a higher value of lead sorption and favorable repeatability.

\section{Effect of pH of solution}

This is the main and essential step of solid phase extraction method. Assessment of optimum pH value for preconcentration and extraction of lead ions in water samples was investigated in the present study. Each point of the curve in Figure 3 shows the average consequence of three experiments which has been done in 0.03 error range. As seen in Figure 3, there is a correlation between the sample solutions with different $\mathrm{pH}$ and determination of $\mathrm{Pb}$ (II) ions. In addition, decreasing the $\mathrm{pH}$ values causes increased the solubility of lead ions in buffer solutions at the $\mathrm{pH}$ of 4. The optimum condition of $\mathrm{pH}$ value was found to be 4 in which, by decreasing and increasing the $\mathrm{pH}$ value, the extraction of lead ions reduced. So, the $\mathrm{pH}$ value was adjusted at 4 for the next tests.

\section{Effect of buffer}

According to the optimum $\mathrm{pH}$ which is 4, three types of buffer were selected including acetate, formate, and citrate buffer. As demonstrated in Table 1, the effect of formate buffer is small at all stages of testing and lead adsorption is almost close to zero. Acetate and citrate buffers revealed better performance in absorbing the lead ions in the solution in $5 \mathrm{~mL}$ and $10 \mathrm{~mL}$ of volume, but the impact of the selected buffers is not sensible for the measurement of lead ions and their use are neglected.

\section{Analysis and preparation of sample}

Modifying flow rates of samples and eluents at the best acquired conditions is an indispensable factor in determination of a suitable recovery for every analyte. So, it has been adjusted at the range of 2-8 mL.min ${ }^{-1}$. The optimum flow rate for all the solutions was $3 \mathrm{~mL}^{-\mathrm{min}^{-1}}$. The recovery of metal ions did not achieve properly at higher and lower than this value.

Some parts of the sample solutions within 100-1000 mL capacity containing $10 \mathrm{mg} \cdot \mathrm{L}^{-1} \mathrm{~Pb}$ (II) were tested in the optimum conditions to determine the proper sample volume. The $\mathrm{pH}$ value was set at 4 by regulating the amount of acid nitric. Finally, the column was eluted by $10 \mathrm{~mL}$ of $1 \mathrm{~mol} \cdot \mathrm{L}^{-1} \mathrm{HNO}_{3}$, and the remnant of solution was given to system for determination. As can be seen in Table 2, the absorption amount slightly enhanced by increasing the volume of solution to $500 \mathrm{~mL}$ and the amount of absorption significantly reduced by increasing the volume. So, $500 \mathrm{~mL}$ was selected as the optimal volume size to continue the test for finding the amount of lead. 
Effect of type and volume of ligand

To determin the lead ions by flame atomic absorption spectrometry, 4 to $10 \mathrm{~mL}$ of several ligands ( $\mathrm{NaCl}, \mathrm{NaF}$ and $\mathrm{KI}$ ) were added to $50 \mathrm{~mL}$ solution containing $10 \mathrm{~mL}$ of $1 \mathrm{~mol} . \mathrm{L}^{-1} \mathrm{HNO}_{3}$. As seen in Table 3 , KI plays a considerable role in increasing the amount of determination value of lead ions. Various amounts of $\mathrm{KI}$ were added to $50 \mathrm{~mL}$ solution containing $10 \mathrm{~mL} \mathrm{HNO}_{3}$ to assess the optimum volume of KI. Table 3 shows that the proper volume for current experiments is $4 \mathrm{~mL}$. The optimum concentration range was tested from 0.0 to $0.1 \mathrm{~mol} / \mathrm{L}^{-1} \mathrm{KI}$. As shown in Figure 4, $0.04 \mathrm{~mol} . \mathrm{L}^{-1}$ is the best concentration for the next level of this research.

Figure 3. The effect of $\mathrm{pH}$ of solution on preconcentration of lead ions

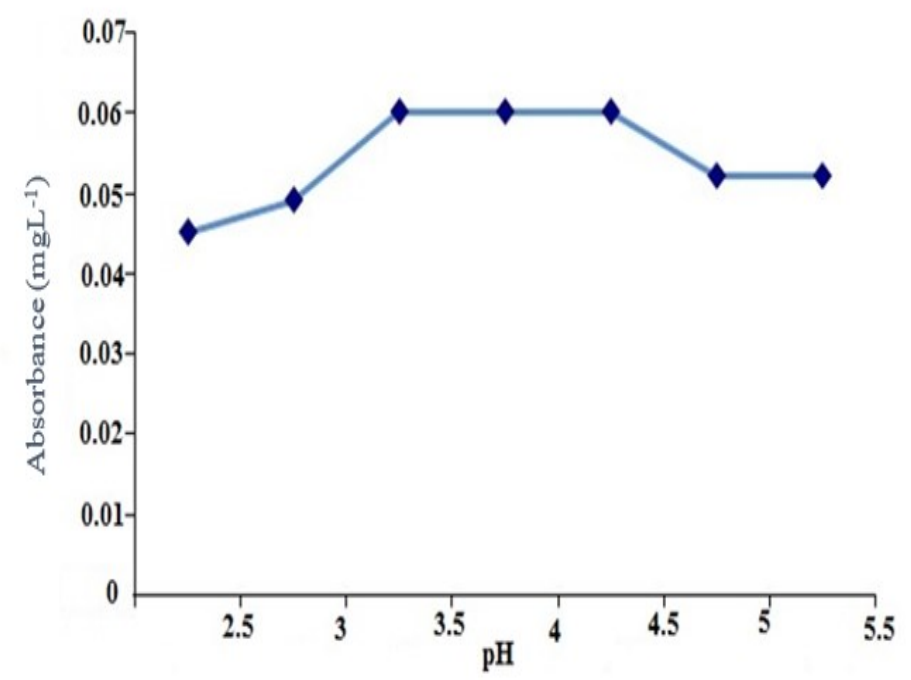

Table 1. Effect of buffer's solution on adsorption of trace lead

\begin{tabular}{ccccccc} 
Buffer & \multicolumn{2}{c}{ Acetate } & \multicolumn{2}{c}{ Formate } & \multicolumn{2}{c}{ Citrate } \\
Volume $(\mathrm{mL})$ & 5 & 10 & 5 & 10 & 5 & 10 \\
Absorbance $\left(\mathrm{mg} / \mathrm{L}^{-1}\right)$ & 0.037 & 0.027 & 0.002 & 0.001 & 0.034 & 0.039 \\
\hline
\end{tabular}

Table 2. The effect of volume of sample on lead adsorption

$\begin{array}{cc}\text { Sample volume }(\mathrm{mL}) & \text { Absorbance }\left(\mathrm{mg} / \mathrm{L}^{-1}\right) \\ 100 & 0.06 \\ 250 & 0.065 \\ 500 & 0.068 \\ 1000 & 0.025\end{array}$


Table 3. The effect of different volumes on preconcentration of lead ions

\begin{tabular}{cccccc}
\multicolumn{2}{c}{ Volume $(\mathrm{mL})$} & $4 \mathrm{~mL}$ & $6 \mathrm{~mL}$ & $8 \mathrm{~mL}$ & $10 \mathrm{~mL}$ \\
Absorbance & $\mathrm{NaCl}$ & - & - & - & 0.001 \\
$\left(\mathrm{mg} / \mathrm{L}^{-1}\right)$ & $\mathrm{NaF}$ & - & - & - & 0.004 \\
& $\mathrm{KI}$ & 0.070 & 0.060 & 0.072 & 0.036 \\
\hline
\end{tabular}

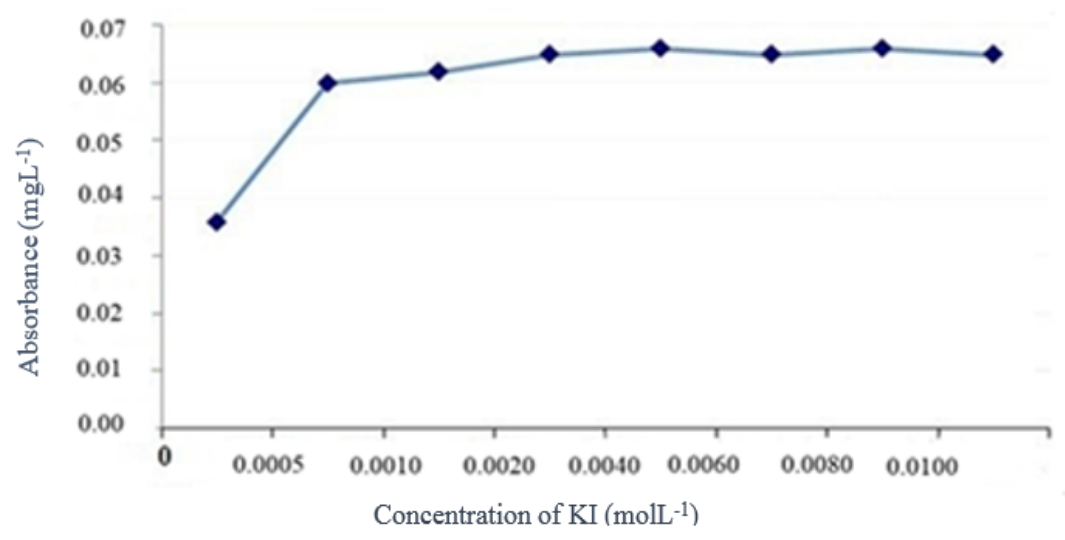

Figure 4. The effect of concentration of KI in measuring the Lead adsorption

\section{Effect of kind, concentration, and volume of eluent}

Different eluents $\left(\mathrm{HCl}, \mathrm{HNO}_{3}\right)$ were examined to study their effect on the determination of lead ions. The results revealed that, in determination of trace metals in analyte, 1.2 mol.L $\mathrm{L}^{-1}$ of $\mathrm{HNO}_{3}$ could be effective more than $95 \%$. Solution was eluted by various concentration of eluent based on Figure 5. Observations showed that $1.2 \mathrm{~mol}^{-\mathrm{L}^{-1}}$ is the steady state of acid concentration variation. The volume changes of eluent were studied by $4 \mathrm{~mL}$ in range of 1 to $5 \mathrm{~mL}$. $5 \mathrm{~mL}$ of $2 \mathrm{M} \mathrm{HNO}_{3}$ was chosen as an optimum volume for determination procedure. The dimensionless ratio of sample volume and eluent volume is known as preconcentration factor and for represented experiment obtained 100.

\section{Effect of sorbent amount and regeneration of sorbent}

Fixing the proper amount of sawdust plays an important role in the determination of lead ions. Reducing the value of sorbent leads determination and deficiency of elution to collect the solution into column which is in the result of utilization of an extra sorbent [33]. Solutions were chosen with different amount of sorbent in an acceptable status to prevent the aforementioned problems. As shown in Figure 6, the maximum absorption of $\mathrm{Pb}$ (II) ions was accessed in $0.25 \mathrm{~g}$ of sorbent that is known as an efficient amount of sawdust for preconcentration of trace $\mathrm{Pb}$ (II). Determination regeneration of sorbent is necessary for extraction of metal ions or suitable analyte enrichment 
process [34, 35]. The evaluated solution was spread on a column containing $0.25 \mathrm{~g}$ sawdust before eluting it by $5 \mathrm{~mL}$ of $1.2 \mathrm{~mol} . \mathrm{L}^{-1} \mathrm{HNO}_{3}$. These processes were done for ten times which showed the efficient level of modifying sawdust during the lead sorption. Table 4 represents the fact that the sorbent can be reused well in which 15.625 adsorption percentage changes can be neglected (Equation 1).

$$
15.625 \%=(0.064-0.054) / 0.064 \times 100
$$

Eq. 1

\section{Analytical features}

Calibration curve was accounted by measuring $\mathrm{Pb}$ (II) in optimum conditions by flame atomic spectrometry in $0.01-0.50 \mathrm{mg} / \mathrm{L}^{-1}$. C is known as the concentration of $\mathrm{Pb}$ (II) at $\mathrm{mg} / \mathrm{L}^{-1}$ and line equation is obtained as $1.028 \mathrm{C}+0.003$ (Figure 7) with $\mathrm{R}^{2}=0.995$. The proportion of 3 product of the relative standard deviation to the calibration curve slope is known as the limit of detection which is equal to $0.48 \mu \mathrm{g} / \mathrm{L}$ in ten times repetition. Present study includes the proper and precise preconcentration and separation of trace $\mathrm{Pb}$ (II) since the relative standard deviation is fewer than 5 percent [36].

\section{Application to real samples}

To examine real samples, three primary models were provided from tap water, Karkhe and Dez rivers. $100 \mathrm{~mL}$ of each real sample was added to $4 \mathrm{~mL}$ of 1 mol.L-1 $\mathrm{KI}$ lead solution and, then, $\mathrm{pH}$ was registered at 4 using distilled water. Results of the determination after eluting the column are shown in Table 5. As seen in Table 5, absorbent and methods employed in this study revealed a high capability to attract and determine the lead from water-soluble naturally found in the nature.

\section{Validation of present work}

Comparatively, the performance of this method with the work which was done about determination and lead capture is shown in the Table 6. The amount of the preconcentration factor (PF), detection limit (DL), and relative standard deviation (RSD) were compared. It was found that, the modified sawdust has the appropriate values for lead capture in all of the presented factors of solid phase extraction method. Also, the recovery rate in a range of 95 to 100 shows the high functionality of the present method in the recovery of lead ions in water samples in nature. 


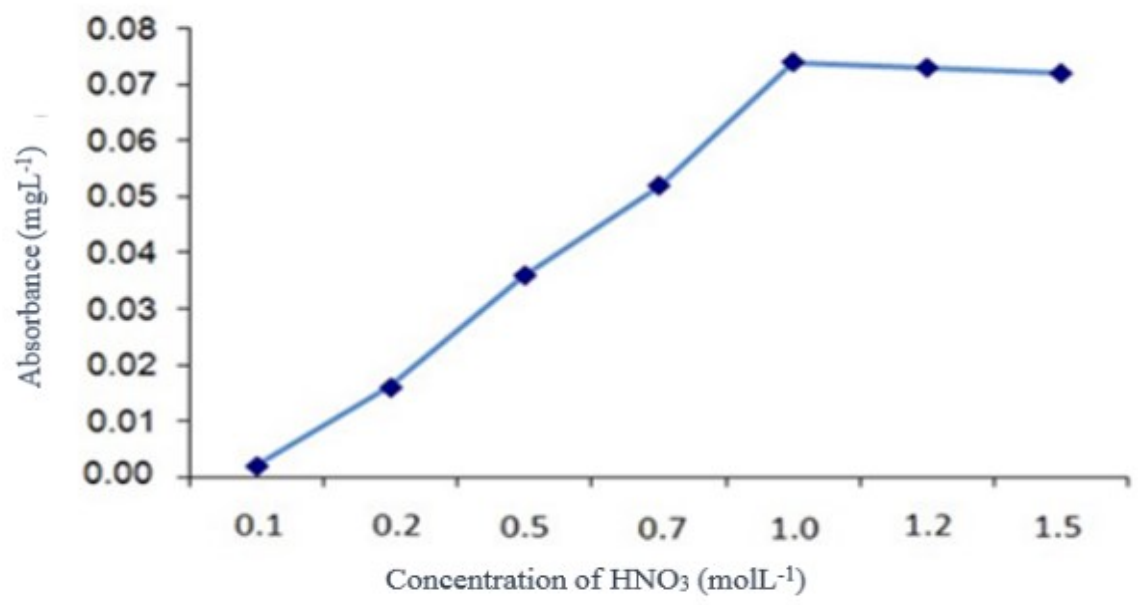

Figure 5. The effect of eluent concentration on Lead adsorption

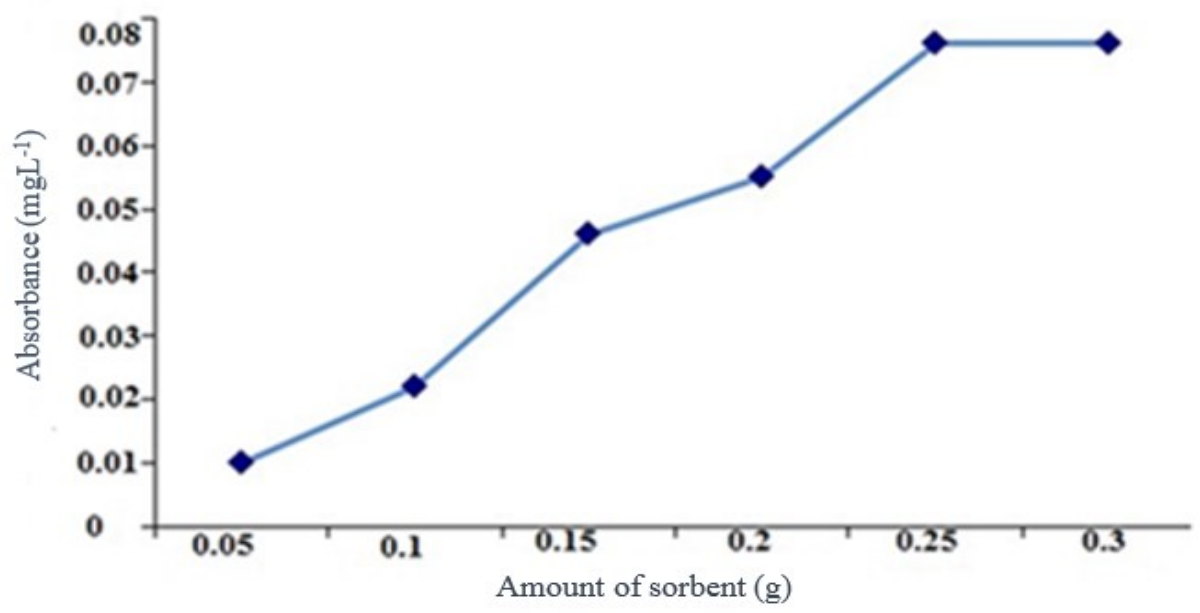

Figure 6. The effect of sorbent amount on lead adsorption

Table 4. The possibility of reusing the sorbent on determination of lead ions

$\begin{array}{ccccccccccc}\text { No } & 1 & 2 & 3 & 4 & 5 & 6 & 7 & 8 & 9 & 10 \\ \text { Absorbance } & 0.064 & 0.061 & 0.059 & 0.057 & 0.055 & 0.056 & 0.055 & 0.055 & 0.053 & 0.054 \\ \left(\mathrm{mg} / \mathrm{L}^{-1}\right) & & & & & & & & & & \end{array}$

\section{Conclusions}

The determination and preconcentration of lead were successfully carried out using modified sawdust and flame atomic absorption. Economical gain, time consuming, and adaptability with 
nature are the advantages of the present method. The impact of effective factors were investigated. The optimum $\mathrm{pH}$ and limit of detection for $\mathrm{Pb}$ (II) were 4 and $0.48 \mu \mathrm{g} / \mathrm{L}$. The preconcentration factor for $\mathrm{Pb}$ (II) and maximum adsorption capacity on the basis of the amount of sorbent were 100 and 76 mg.g-1, respectively. The represented new sorbent revealed a high absorption capacity and preconcetration factor. The results showed that, the applied experiment was sensitive and precise to the determination of lead ions in real water samples.

Figure 7. The calibration curve of determination of $\mathrm{Pb}(\mathrm{II})$ in this research

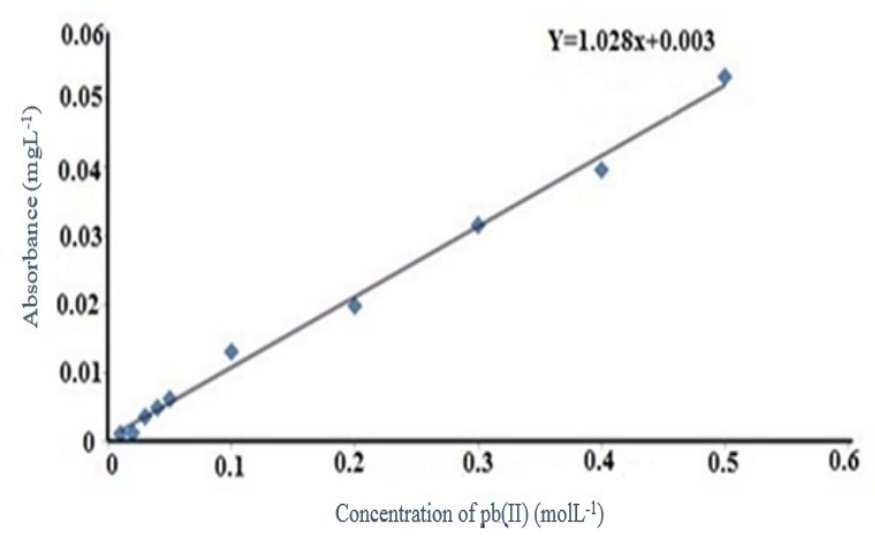

Table 5. Preconcentration of $\mathrm{Pb}(\mathrm{II})$ ions in real samples

\begin{tabular}{cccc} 
Sample & $\begin{array}{c}\text { Getting } \mathrm{Pb}(\mathrm{II}) \\
\mathrm{mgL}^{-1}\end{array}$ & $\begin{array}{c}\text { Adding Pb(II) } \\
\mathrm{mgL}^{-1}\end{array}$ & Recovery (\%) \\
Not Detected & 0.0 & - \\
Tap water & 0.095 & 0.1 & 95.2 \\
& 0.195 & 0.2 & 97.5 \\
Not Detected & 0.0 & - \\
Karkhe river water water & 0.094 & 0.1 & 94.6 \\
& 0.192 & 0.2 & - \\
& Not Detected & 0.0 & 100 \\
\hline
\end{tabular}


Table 6. Comparing previous researches with present method in preconcentration and determination of $\mathrm{Pb}(\mathrm{II})$

\begin{tabular}{cccc} 
PF & LOD & RSD \% & Ref \\
50 & 0.65 & $<5$ & 19 \\
50 & - & - & 37 \\
60 & 0.02 & $<10$ & 11 \\
50 & 23.2 & 2.9 & 20 \\
150 & 3.19 & 3.19 & 38 \\
50 & 0.75 & 1 & 39 \\
125 & 0.3 & $<10$ & 40 \\
50 & 0.29 & 1.8 & 22 \\
200 & 0.056 & $<8$ & 41 \\
100 & 0.48 & 2.1 & Present study \\
\hline
\end{tabular}

\section{Acknowledgements}

The authors would like to appreciate Prof. Dr. Babak Mokhtari for his guidance during my researches. we are also indebted to the Department of Chemistry of Azad University of Ahvaz, all stuff and laboratory assistants, for their support and coopration. Finally, we would like to thank the stuff of the Analytical Laboratory, especially Ms Ladan Kaviani for her valuable assistance during the course of my study.

\section{Disclosure Statement}

No potential conflict of interest was reported by the authors.

\section{References}

[1]. Castro R.S.D., Caetano L., Ferreira G., Padilha P.M., Saeki M.J., Zara L.F., Martines M.A.U. Ind. Eng. Chem. Res., 2011, 50:3446

[2]. Dabas T., Saçmac S., Ülgen A., Kartal S. Food Chem., 2015, 174:594

[3]. Dabas T., Ülgen A., Kartal S. J. Ind. Eng. Chem., 2015, 28:316

[4]. Hossein Baki M., Shemirani F., Khani R. J. Food. Sci., 2013, 78:797

[5]. Khalid N.R.S., Ahmad S. Sep. Sci. Technol., 2005, 2427:43

[6]. Haman DJ.B.Z., Proceedings of the 10 $10^{\text {th }}$ International Conference on Environmental Science and Technology, Kos Island, Greece. 2007; p 246

[7]. Ebrahimzadeh H., Behbahani M. Arab J. Chem., 2013, 10:2499 
[8]. Hossien-poor-Zaryabi M., Chamsaz M., Heidari T., Arbab Zavar M.H., Behbahani M. Food Anal. Method., 2014, 352:359

[9]. Benzo Z., Velosa M. J. Food Sci., 2006, 222:4

[10]. Behbahani M., Babapour M., Amini M.M., Sadeghi O., Bagheri A., Salarian M., Rafiee B. Am. J. Anal. Chem., 2014, 90:98

[11]. Divrikli U.K.A., Soylak M., Elci L. J. Hazard. Mater., 2007, 459:64

[12]. Liu Y.C.X., Guoa Y., Menga S. J. Hazard. Mater. B, 2006, 389:94

[13]. Behbahani M., Najafi M., Amini M.M., Sadeghi O., Bagheri A., Ghareh Hassanlou P. J. Ind. Eng. Chem., 2014, 2248:2255

[14]. Behbahani M., Abolhasani J., Amini M.M., Sadeghi O., Omidi F., Bagheri A., Food Chem, 2015, 1207:1212

[15]. Behbahani M., Bide Y., Salarian M., Niknezhad M., Bagheri S., Bagheri A. Food Chem., 2014, 14:19

[16]. Behbahani M., Amini M.M., Esrafili A., Farzadkia M., Bagheri A. Food Chem., 2015, 14:19

[17]. Dasbas T.S., Çankaya N., Soykan C. Food Chem., 2016, 68:73

[18]. Komjarova I.B.R. Anal. Chim. Acta., 2006, 221:8

[19]. Melek E.T.M., Soylak M. Anal. Chim. Acta., 2006, 578:213

[20]. Bermejo-Barrera P., Nancy M.A., Cristina D.L., Adela B.B. Microchim. Acta., 2003, 101:8

[21]. Mendli D. J. Food Sci., 2012, 181:6

[22]. Marahel F., Shokrollahi G., Montazerozohori M., Davoodi S. Chemosphere, 2009, 583:9

[23]. Pyrzynska K. TrAC Trends Anal. Chem., 2010, 718:27

[24]. Kaur A.G.U. J. Mater. Chem., 2009, 8279:89

[25]. Sari A.D.U., Tuzen M. Chem. Eng. J., 2011, 155:61

[26]. Rafatullaha M.S.O., Hashima R., Ahmad A. J. Hazard. Mater., 2009, 969:77

[27]. Vania M.M.R., Villanueva R.A.C., Garnica-Romo M.G., MartInez-Flores H.E. J. Food Sci., 2012, 71:10

[28]. Kaczala F.M.M., Hogland W. Biores. Technol., 2009, 235:43

[29]. Hao L., Liu Q. Li X., Du Z., Wang P. RSC Advances, 2014, 4:49569

[30]. Shi B., Li G., Wang D., Feng C., Tang H. J. Hazard. Mater., 2007, 143:567

[31]. Wang H., Yuan X., Zeng G., Peng L., Liao K., Peng L., Xiao Z. Environ. Sci. Pollut Res., 2014, 21:11552

[32]. Sabermahani F., Bahrami H. Arab J. Chem., 2012, 9:1700

[33]. Tunceli A., Turker R. Talanta, 2002, 1199:1204

[34]. Gouda A.A., Al-Ghannam Gouda S.M. Food Chem., 2016, 202:409

[35]. Feist B., Mikula B. Food Chem., 2014, 147:302 
[36]. Burham N., Azeem S.A., El-Shahat M.F. Cent. Eur. J. Chem., 2009, 945:54

[37]. Tewari P.K., Singh A.K. Fresenius J. Anal. Chem., 2000, 562:567

[38]. Ramesh A., Mohan K.R., Seshaiah K. Talanta, 2002, 243:252

[39]. Tuzen M.S.K., Soylak M. J. Hazard. Mater., 2008, 632:9

[40]. Saracoglu S., Soylak M., Elci L. J. Anal. Chem., 2003, 1127:31

[41]. Narin I., Soylak M., Kayakirilmaz K., Elci L. J. Anal. Lett., 2003, 641:658

How to cite this manuscript: Rashin Andayesh*, Shahla Elhami. Application of modified sawdust for solid phase extraction, preconcentration and determination of trace lead in water samples. Asian Journal of Green Chemistry, 3(4) 2019, 536-549. DOI: 10.33945/SAMI/AJGC/2019.4.10 